\title{
Investigation of dental caries prevalence, Decayed, Missing, and Filled Teeth (dmft and DMFT indexes) and the associated factors among 9 - 11 years old children
}

\author{
Ali Alami \\ Gonabad University of Medical Sciences

\section{Saeed Erfanpoor} \\ Gonabad University of Medical Sciences \\ Elaheh Lael-Monfared \\ Shaheed Beheshti University of Medical Sciences \\ Ali Ramezani \\ Gonabad University of Medical Sciences \\ Alireza Jafari ( $\sim$ jafari.ar94@gmail.com ) \\ Gonabad University of Medical Sciences https://orcid.org/0000-0003-1390-9830
}

Research article

Keywords: Elementary students, School, dmft, DMFT, Children, Oral health

Posted Date: January 22nd, 2020

DOI: https://doi.org/10.21203/rs.2.21545/v1

License: (c) (i) This work is licensed under a Creative Commons Attribution 4.0 International License.

Read Full License 


\section{Abstract}

Background: Oral hygiene is one of the most important health issues in children that affects the health of children. This study aimed to investigate dental caries prevalence, Decayed, Missing, and Filled Teeth (dmft and DMFT Indexes) and the associated factors among 9-11 years old children.

Materials and Methods: This cross-sectional study was performed on 4226 primary school students aged 9-11 years old using the census method in Iran. Data were collected by valid and reliable researcher-made checklists. Data analysis was performed using SPSS software version 24 and using Kruskal Wallis, MannWhitney, and Logistic Regression tests.

Results: The prevalence of permanent and primary dental caries in all students was $39.73 \%$ and $67.72 \%$. The mean (standard deviation) of DMFT in the 9,10 and 11 age groups were $0.6(1.11), 0.97$ (1.39) and 1.23 (1.63), respectively. The mean (standard deviation) dmft in the 9,10 and 11 age groups were 3.14 (2.56), 2.46 (2.34) and 1.37 (1.84), respectively. There was a significant difference in DMFT and dmft between age groups $(P<0.001)$. Results of multivariate logistic regression showed that there is a significant relationship between gender, birth rate, place of residence, mother's education, father's education and use of mouthwash with DMFT index $(P<0.05)$. The results of multivariate logistic regression showed that the variables of insurance, residence and mother's job were significantly correlated with dmft index $(P<0.05)$.

Conclusion: In this study, the prevalence of dental caries was high. Variables of gender, birth rate, parental education, place of residence, use of mouthwash, having health insurance and mother's job were effective in predicting dental caries in students. it seems necessary to hold educational courses to increase awareness among students, educators, and parents about oral Health. Keywords: Elementary students, School, dmft, DMFT, Children, Oral health

\section{Background}

Oral and dental health is an indispensable part of the public health and well-being in society [1]. One of the most important oral and dental diseases is dental caries. Dental caries is a multidimensional disease developed because of increasing consumption of nutrients, alcohol, drug abuse, smoking, poor oral care methods, and improper use of healthcare services, consumption of sugars and sweets, as well as dry mouth[2-6]. The prevalence of dental caries is diminishing in developed countries because of taking preventive measures, while in developing countries the prevalence of dental caries is growing in pediatrics [7]. The important indices for measuring dental caries of permanent and primary teeth are DMFT and dmft, respectively. In these indices, the number of permanent teeth ( $T$ ), decayed teeth (D), missing due to caries (M), or filled because of caries (F) is evaluated. This index is used as an important criterion to reflect the status of oral and dental health and plays a significant role in healthcare decision-making $[8,9]$. The problems associated with dental caries lead to diminished quality of life as well as increased economic costs for the patients [10]. The prevalence of caries is high among children, and the pain resulting from 
caries causes increased school absence as well as the reduced ability for learning, the impaired ability for eating food, increased talking problems, and eventually reduced rate of growth for children [11, 12].

The results of a study on students in Nepal indicated that $45 \%$ of students have dental caries; $31 \%$ of them suffer toothache, and only $24 \%$ of them brush their teeth twice per day [13]. A study on Egyptian students indicated that $74 \%$ of them had dental caries, associated with consuming sweets, parental tooth brushing, and their socioeconomic status [14]. The results of a meta-analysis on Persian Gulf countries in 2018 showed that $80 \%$ of students have dental caries, and the mean dmft in them was reported as high and equal to 5.14 [15].

Investigation of the oral and dental health status of children, 6-12 years old, indicated that total caries and total prevalence of untreated dental caries in the study population have been 93 and $30 \%$, respectively [16]. The results of a study on 6-11-year-old Indian children revealed that the prevalence of dental caries was $79 \%$ in them, with the mean dmft and DMFT of 2.97 and 0.17 , respectively [17]. Since DMFT value is reported provincially and considering the geographical, cultural, economic and other differences in any region and the necessity of achieving special results in every region, to adopt proper healthcare and managerial decisions in line with every society the results should be reported specifically in line with every society so that proper health decisions could be made and the issue would be addressed specifically. The present study has been performed to determine the dental caries prevalence, Decayed, Missing, and Filled Teeth (dmft and DMFT indexes) and the associated factors among 9 - 11 years old children in Gonabad and Bajestan Towns.

\section{Methods}

The present study is a cross-sectional study which was performed on 4226 students in elementary school in Gonabad and Bajestan towns, Iran. In this study, all male and female students aged 9 to 11 years old were enrolled by the census method in the study.

\section{Data collection}

A week before the study, the goals of the research project were explained to the parents of the students and then to the students. After the informed consent of the students and their parents, the study process began. Students were also assured that study participation was optional and that their information would remain confidential with the research team. The inclusion criteria were The students of elementary school, residing in the city of Gonabad or Bajestan.

\section{Measurement tools}

A researcher-designed checklist consisting of two parts was used to collect the data. The first part of the checklist was about the demographic variables of the students, which they completed by self-report. This section included questions such as age, gender, parental education, parental job status, residence, number of family members, rate of toothbrushes per day, use of dental floss and mouthwash, etc. 
The second part of the checklist included questions that were completed by the physician during the student examination. In this section, the number of decayed, missing, and filled primary teeth(dmft) of the students were examined by a physician. The number of decayed, missing, and filled permanent teeth(DMFT) was also evaluated. The face and content validity of the instrument has been reviewed and approved by dental professionals, health education and health promotion professionals.

\section{Data Analysis}

Data analysis was performed using SPSS 24 software. Before analyzing the data, the data were checked for normality and non-parametric tests were used to analyze the data. Descriptive statistics and related charts, number and percentage (for qualitative variables) and mean and standard deviation (for quantitative variables) were used to describe the data. Data were analyzed by inferential statistics using chi-square, Kruskal-Wallis, Mann-Whitney, and univariate and multivariate logistic regression tests (because the dependent variable was qualitative two-way).

In this study, using logistic regression, the relationship between DMFT and dmft index with variables in this study was evaluated in children aged 11-9 years. At first, the variables were included in the univariate model and each of them with a significance level of less than $0.2(P<0.2)$ was entered into the multivariate model (reference). In this study, the significance level was considered less than 0.05 for data analysis.

\section{Results}

The study was conducted on 4226 students aged 9 to 11 years. In this study, 34.54\% ( $n=1460)$ were in the 9-year age group, $33 \%(n=1392)$ in the 10-year age group and $32.5 \%(n=1374)$ in the 11-year age group. Of the participants, $51 \%$ were girls $(n=2158)$ and $49 \%$ boys $(n=2068)$.

Also, $73 \%(n=3069)$ were residents of the urban. Only $8 \%(n=342)$ of students reported not using a toothbrush. Only $25 \%(n=1018)$ of students used Mouthwash and $18 \%(n=725)$ used dental floss. Other demographic information is visible in Tables 1 and 2.

The prevalence of permanent dental caries in all students was $39.73 \%$. The prevalence of permanent dental caries in 9,10 , and 11 years old was $28.90 \%(n=422), 43 \%(n=598)$ and $48 \%(n=659)$, respectively. The mean (standard deviation) of DMFT in the 9, 10 and 11 age groups were 0.6 (1.11), 0.97 (1.39) and 1.23 (1.63), respectively. There was a significant difference and this rate was higher in the 11-year age group $(P<0.001)$ (Table 1). According to the results, there was a significant relationship between DMFT index and gender, place of birth, parental education level, mother's occupation, use of mouthwash and birth rate $(P<0.05)$. The results also showed that DMFT levels in girls were significantly higher than boys $(\mathrm{P}<0.001)$ (Table 1).

The prevalence of primary dental caries in all students was $67.72 \%$. The prevalence of primary dental caries in the age group of 9,10 and 11 years old was $79.20 \%(n=1156), 71.5 \%(n=995)$, and $51.7 \%$ $(\mathrm{n}=711)$, respectively. The mean (standard deviation) dmft in the 9,10 and 11 age groups were 3.14 (2.56), $2.46(2.34)$ and 1.37 (1.84), respectively. There was a significant difference in the age group of 9 years 
$(P<0.001)$ (Table 2). The results also showed that the dmft index was significantly correlated with variables of residence, father's education level, having insurance, maternal occupation, using dental floss and toothbrush $(P<0.05)$. The results also showed that decayed teeth $(\mathrm{dt})$ was significantly higher in boys than girls $(P<0.05)$ (Table 2$)$.

In examining the relationship between DMFT and demographic variables, multivariate logistic regression results showed that variables of gender with odds ratio (2.08), birth rate with odds ratio (1.38), and residence with odds ratio (1.18), mother's diploma and sub-diploma with odds ratio (1.25), mother's college education with odds ratio (1.09), father's diploma and sub-diploma with odds ratio (0.93), father's college education with odds ratio (0.77) and mouthwash with odds ratio (0.84) were statistically significant relationship with DMFT index in children 9-11 years old $(P<0.05)$ (Table 3).

The results of multivariate logistic regression on the relationship between $\mathrm{dmft}$ and demographic variables showed that variables of insurance with odds ratio (0.57), residence with odds ratio (1.18), mother's government jobs with odds ratio (1.34), other mother's occupations with odds ratios (1.06) were significant relationship with $\mathrm{dmft}$ index of children age $11-9$ years $(P<0.05)($ Table 4$)$.

\section{Discussion}

The present study has been performed to determine the dental caries prevalence, Decayed, Missing, and Filled Teeth (dmft and DMFT indexes) and the associated factors among 9 - 11 years old children. In the present study, the prevalence of permanent and permanent dental caries was $39.73 \%$ and $67.72 \%$ in students, respectively. The results of a 2015 Kumar study of Indian students showed that $47 \%$ of them had tooth caries [18]. The results of a study by Zhang on Chinese students also showed that the prevalence of dental caries was $40 \%[19]$. The results of a study on your children in Ethiopia showed that $36.3 \%$ had caries[4].

The results of present study indicated that $90 \%$ of students use the toothbrush, $25 \%$ mouthwash, and $18 \%$ dental floss. In study by Mohamadkhah, tooth brushing, flossing, and use of mouthwash have been reported as $69 \%, 34 \%$, and $69 \%$, respectively[20]. Also, the study by Babaei indicated that $59.5 \%$ of students brush their teeth daily [21]. In the study by Halboub, the frequency of tooth brushing (less than twice per day) was reported as $24 \%[22]$. Considering the discrepancy of the age group across different studies, the different findings seem to be normal. Furthermore, since sometimes flossing can cause the incidence of pain, gum bleeding, and discomfort, the person is discouraged to floss or to care for oral and dental health. Lack of proper knowledge about flossing especially in the regions in which food residual may remain could be a reason for the low percentage of flossing.

In the present study, the rate of decayed, missing and filled teeth was the highest in the permanent teeth of 11 years old and in the primary teeth of 9 years old. Overall, the dmft and DMFT indices showed the highest values at 9 and 11 years, respectively. It seems that since the age of 9 years old, children have more primary teeth and the $\mathrm{dmft}$ index in this group is more likely than other age groups. Also in the age 
group of 11 years old, since children have more permanent teeth, the DMFT index is more likely than other age groups.

Based on the logistic regression results, in this study the girls had a higher rate of tooth decayed and repair compared to boys, and had overall a higher DMFT; this index was likely to be twice as large in girls than in boys. The results of Amirabadi and Nag studies, in line with the results of the present study, showed that girls had a higher rate of caries and repair than boys and overall DMFT index[23, 24]. The results of the study by Shaffer showed that girls in comparison to boys have 1.5 times fewer damaged teeth, and the DMFT of boys is larger than that of girls' [25]. This incongruence in the results of the studies can be due to the different age of the target groups or the method of knowledge acquisition by students regarding oral and dental health. Furthermore, physiological and behavioral differences in girls and boys, earlier growth of teeth in girls, and the high percentage of girls at home causing more consumption of sweets can justify the higher DMFT in girls[26].

In the present study, the rate of decayed, missing teeth, and DMFT index were higher in students living in villages as compared to city-dweller students. Furthermore, the rate of filled teeth was higher in the urban regions, while the rate of missing and decayed teeth, as well as dmft index, were higher in the rural region. In that study by Babaei, the place of residence of children, in terms of living in a city or village, had a significant relationship with the rate of dental decayed [8]. The reason of these discrepancies can be different access to dental care services, lower priority of oral and dental healthcare in comparison to other needs, differences in implementation of healthcare and preventive programs of oral and dental health, weakness in implementing educational programs, economic and cultural differences, and lack of supervision by parents regarding proper teeth cleaning by children. The results of Arora's study showed that the rate of DMFT in urban students was lower than that of rural students, which was in line with the results of the present study[27]. In the study by Gorbatova, no difference has been reported between rural and urban regions. The similarity of service provision in both rural and urban regions in the mentioned study has been reported as the reason for the discrepancy with the results of the present study[28].

In the present study, it was found that the students whose fathers and mothers had academic education had lower DMFT index as well as a lower rate of decayed and missing teeth in both permanent and primary teeth while having a higher rate of filled teeth. In the study by Pakpour, the maximum positive and significant correlation was observed between the fathers' level of education and filled teeth of children [29].

The results of the studies of Abbass, Mohebi, and Nurelhuda showed that there was a significant relationship between parents 'education and students' oral health status, which was in line with the results of the present study[14, 30, 31]. Concerning the importance of teeth and their role in proper nutrition, providing beauty and formation of speech in the early years of life, developing caries can signal a major defect in the early stages of development for the child's health. In this regard, parental education can be one of the principal factors in promoting the dental and oral health status of children. Furthermore, higher parental education level leads to their better awareness about oral and dental health status and eventually greater supervision of parents on the oral and dental health of children. 
The results of this study also showed that father unemployment is an important factor for the high rate of decay. There is also a significant relationship between a mother's employment and dmft index. Shaghaghian found the mother's job as one of the important factors for a student's dental decayed [32]. The results of studies have shown that the average social status of the family is associated with dental caries, where children with a higher socioeconomic level have fewer decayed, missing, and filled teeth [33, 34]. Low socioeconomic status of families can be associated with poor eating habits and unhealthy lifestyles and can be effective in causing dental caries in children[35].

Based on the results acquired in this study, those with no health insurance had a higher $\mathrm{dmft}$ and more decayed teeth. Considering the huge dentistry costs, it seems that lack of health insurance can be a reason for no referral and dental restoration. In this regard, Babaei reported that $41.1 \%$ of students cited the expensiveness of dentistry costs as the reason for not referring to a dentist [8]. The results of the study by Amirabadi also showed that DMFT is higher among the students who do not refer to a dentist for annual examinations than among other students [23]. Nevertheless, this problem can be mitigated to some extent through the support of dental insurance companies and governmental support.

The results of this study indicated that students who used mouthwash had higher DMFT index as well as a greater rate of decayed in both permanent and primary teeth. As a justification, usage of these products is recommended for some special cases, because long-term and improper use of mouthwashes can lead to adverse consequences and damages to dental health. It seems that in the present study the students had not used mouthwash properly, and thus damaged their teeth. The results showed that the usage of mouthwash alongside regular tooth brushing contributes to better oral and dental health [20]. On the other hand, based on the results, not all mouthwashes available in the market are useful and some of them can damage the teeth. Hence, the use of mouthwash should be prescribed by a dentist [36].

Based on the findings of the present study, it was observed that not flossing leads to increased dmft index as well as the rate of decayed, while tooth brushing results in reduced dmft along with the rate of decayed in primary teeth. Flossing as a means for taking care of oral and dental health can help in the removal of dental plaques mechanically thereby removing the plaques that form between teeth [36]. The results of a study showed that the students who regularly floss have better oral and dental health compared to those who floss occasionally [37].

Also, in the present study, those who brushed their teeth had a lower DMFT compared to other students, though there was no significant relationship. The results of a meta-analysis study indicated that the students who floss regularly are 1.5 times less likely to suffer dental caries and problems in comparison to those who toothbrush occasionally and irregularly [38]. It has also been found that improper use of a toothbrush can cause damage to the teeth [36]. Possibly, in the present study, the students had not been trained about the proper way of tooth brushing and they may have damaged their teeth unintentionally. Furthermore, since dental caries is a multidimensional disease, the lack of a statistical relationship may be justified. 
The present study also showed that DMFT is higher and dental caries are more frequently observed in fourth and younger children; this value is 1.38 times greater in fourth children and younger compared to first to third children. In primary teeth, the number of restored teeth is higher in students who are the first, second, or third children. In this regard, Al-Meedani, found that the oral and dental health of children in populated families is poorer than in less populated families[39]. It can be justified that the attention of parents to children diminishes as their number increases; thus the opportunity for educating them and raising awareness in them about the impact of decay-causing materials on their dental health and supervision on oral as well as dental health diminish.

\section{Conclusions}

According to the results of this study, the prevalence of dental caries was high. Variables of gender, birth rate, parental education, place of residence, use of mouthwash, having health insurance and mother's job were effective in predicting dental caries in students. The results showed that the use of dental floss and mouthwash was poor. Since health care has a direct impact on the oral health index, to improve oral health, it seems necessary to hold educational courses for students about the proper use of toothbrushes, toothpaste, and mouthwash containing fluoride. Also, course training is needed to increase awareness among students, educators, and parents about improving children's diet and emphasizing reducing sugar consumption; using preventive methods such as topical fluoride therapy. Overall, designing coherent programs to promote students' behavior in the field of preventive oral care seems essential.

\section{Abbreviations}

DMFT: Decayed, Missing, and Filled permanent Teeth; dmft: decayed, missing, and filled primary Teeth; OR: Odds ratios

\section{Declarations}

\section{Acknowledgments}

We would like to thanks all students who assisted the authors to run this research project.

\section{Authors' contributions}

Authors AA, ELM, SE and AJ designed the study. AA, ELM, AR and AJ participated in the conception of the study. SE and AJ managed and conducted the statistical analyses and interpreted the data. AJ, SE, ELM and AR wrote the first draft and AA, ELM and AJ revised it to make the final manuscript. All authors have approved the final manuscript.

\section{Funding}

No financial support was received for this study.

\section{Availability of data and materials}


The data sets used and/or analyzed during the current study were available from the corresponding author on reasonable request.

\section{Ethics approval and consent to participate}

This study is based on a research project approved by Ethics Committee of Gonabad University of Medical Sciences with the code of ethics IR.GMU.REC.1394.100. All procedures performed in this study were in accordance with the ethical standards of the institutional and/or national research committee and with the 1964 Helsinki declaration and its later amendments or comparable.

\section{Consent for publication}

Not applicable

\section{Conflicts of interest}

The authors have no conflicts of interest

\section{Authors' contributions}

Authors AA, AJ and SE Contributed to conception, design, data acquisition and interpretation, performed all statistical analyses, drafted and critically revised the manuscript. ELM and AR Contributed to conception, design, data acquisition and interpretation, drafted and critically revised the manuscript.

\section{Funding}

No financial support was received for this study.

\section{Conflicts of interest}

The authors have no conflicts of interest

\section{References}

1. Hannan M, Chowdhury M, Khan M, Chowdhury A, Shahidullah K, Saha A, Anjum A: Prevalence of Gingivitis, Plaque accumulation and Decayed, Missing and Filled Teeth among slum population in Bangladesh. Bangladesh Medical Research Council Bulletin 2014, 40(2):47-51.

2. PriyanKa K, SuDhir KM, Reddy VCS, Kumar RK, Srinivasulu G: Impact of alcohol dependency on oral health-a cross-sectional comparative study. Journal of clinical and diagnostic research: JCDR 2017, 11(6):ZC43.

3. Shah AH, ElHaddad SA: Oral hygiene behavior, smoking, and perceived oral health problems among university students. Journal of International Society of Preventive \& Community Dentistry 2015, 
5(4):327.

4. Ayele FA, Taye BW, Ayele TA, Gelaye KA: Predictors of dental caries among children 7-14 years old in Northwest Ethiopia: a community based cross-sectional study. BMC Oral Health 2013, 13(1):7.

5. Castilho ARFd, Mialhe FL, Barbosa TdS, Puppin-Rontani RM: Influência do ambiente familiar sobre a saúde bucal de crianças: uma revisão sistemática. Jornal de Pediatria 2013, 89:116-123.

6. Punitha VC, Amudhan A, Sivaprakasam P, Rathanaprabu V: Role of dietary habits and diet in caries occurrence and severity among urban adolescent school children. Journal of pharmacy \& bioallied sciences 2015, 7(Suppl 1):S296-S300.

7. Veiga N, Pereira C, Amaral O: Prevalence and determinants of dental caries in a sample of schoolchildren of Sátão, Portugal. Revista Portuguesa de Estomatologia, Medicina Dentária e Cirurgia Maxilofacial 2014, 55(4):214-219.

8. Babaei Hatkehlouei M, Tari H, Goudarzian AH, Hali H: Decayed, Missing, and Filled Teeth (DMFT) Index among First-grade Elementary Students in Mazandaran Province, Northern Iran. International Journal of Pediatrics 2017, 5(6):5069-5077.

9. Murray Thomson W: Epidemiology of oral health conditions in older people. Gerodontology 2014, 31:9-16.

10. Kim H-N, Han D-H, Jun E-J, Kim S-Y, Jeong S-H, Kim J-B: The decline in dental caries among Korean children aged 8 and 12 years from 2000 to 2012 focusing SiC Index and DMFT. BMC oral health 2016, 16(1):38.

11. Bagramian RA, Garcia-Godoy F, Volpe AR: The global increase in dental caries. A pending public health crisis. Am J dent 2009, 22(1):3-8.

12. Dimberg L, Lennartsson B, Bondemark L, Arnrup K: Oral health-related quality-of-life among children in Swedish dental care: The impact from malocclusions or orthodontic treatment need. Acta Odontologica Scandinavica 2016, 74(2):127-133.

13. Dixit LP, Shakya A, Shrestha M, Shrestha A: Dental caries prevalence, oral health knowledge and practice among indigenous Chepang school children of Nepal. BMC oral Health 2013, 13(1):20.

14. Abbass MMS, Mahmoud SA, El Moshy S, Rady D, AbuBakr N, Radwan IA, Ahmed A, Abdou A, Al Jawaldeh $A$ : The prevalence of dental caries among Egyptian children and adolescences and its association with age, socioeconomic status, dietary habits and other risk factors. A cross-sectional study. F1000Research 2019, 8:8-8.

15. Al Ayyan W, Al Halabi M, Hussein I, Khamis A, Kowash M: A systematic review and meta-analysis of primary teeth caries studies in Gulf Cooperation Council States. The Saudi Dental Journal 2018, 30(3):175-182.

16. Ramazani N, Rezaei S: Evaluation of the prevalence of clinical consequences of untreated dental caries using PUFA/pufa index in a group of Iranian children. Iranian Journal of Pediatrics 2017, 27(1).

17. Hiremath A, Murugaboopathy V, Ankola AV, Hebbal M, Mohandoss S, Pastay P: Prevalence of dental caries among primary school children of India-A cross-sectional study. Journal of clinical and diagnostic research: JCDR 2016, 10(10):ZC47. 
18. Kumar S, Kumar A, Badiyani B, Kumar A, Basak D, Ismail MB: Oral health impact, dental caries experience, and associated factors in 12-15-year-old school children in India. International journal of adolescent medicine and health 2017, 29(2).

19. Zhang S, Xu B, Liu J, Lo EC, Chu C-H: Dental and periodontal status of 12-year-old Dai school children in Yunnan Province, China: a cross-sectional study. BMC oral health 2015, 15(1):117.

20. Mohamadkhah F, Shokravi FA, Karimy M, Faghihzadeh S: Effects of lecturing on selfcare oral health behaviors of elementary students. Med J Islam Repub Iran 2014, 28:86.

21. Babaei N, Belyad S, Moradi A: Evaluation of Oral Hygiene and Related Oral Health Behaviors among Students Studying Science in Meshgin City. Journal of Health 2019, 10(1):118-128.

22. Halboub E, Dhaifullah E, Yasin R: Determinants of dental health status and dental health behavior among S ana'a U niversity students, Y emen. Journal of investigative and clinical dentistry 2013, 4(4):257-264.

23. Amirabadi F, Bazafshan E, Dehghan J, Zazouli MA: Evaluation of DMFT index in the 8-12 years old students of Zahedan City, Iran. Iranian journal of health sciences 2015, 3(2):52-60.

24. Nag R, Bihani V, Panwar V, Acharya J, Bihani T, Pandey R: Prevalence of dental caries and treatment needs in the school going children in Bikaner, Rajasthan-An observational study. Journal of the Indian Dental Association 2012, 6(1):12.

25. Shaffer JR, Leslie EJ, Feingold E, Govil M, McNeil DW, Crout RJ, Weyant RJ, Marazita ML: Caries Experience Differs between Females and Males across Age Groups in Northern Appalachia. Int $J$ Dent 2015, 2015:938213-938213.

26. Martínez-Mier E, Zandoná A: The Impact of Gender on Caries Prevalence and Risk Assessment. Dental clinics of North America 2013, 57(2):301-315.

27. Arora B, Khinda VI, Kallar S, Bajaj N, Brar GS: Prevalence and comparison of dental caries in 12 year old school going children in rural and urban areas of Ferozepur city using sic index. Dent Oral Craniofac Res 2015, 1(2):38-41.

28. Gorbatova M, Grjibovski A, Gorbatova L, Honkala E: Dental caries experience among 12-year-old children in Northwest Russia. Community dental health 2012, 29(1):20.

29. Pakpour Haji Agha A, Ehsani N, Pouresmaeil M, Alijanzadeh M: Investigate the situation of oral health in preschool students of Alborz province. J Isfahan Dent Sch 2016, 12(1):72-80.

30. Mohebi S, Ramezani A, Matlabi M, Mohammadpour L, Nour NSA, Hosseini E: The survey of oraldental health of grade 3 students of Gonabad primary schools in 2007. Ofogh-e-Danesh 2009, 14(4):69-76.

31. Nurelhuda NM, Ahmed MF, Trovik TA, Åstrøm AN: Evaluation of oral health-related quality of life among Sudanese schoolchildren using Child-OIDP inventory. Health and quality of life outcomes 2010, 8(1):152.

32. Shaghaghian S, Abolvardi M, Akhlaghian M: Factors affecting dental caries of preschool children in Shiraz, 2014. Journal of Dentistry 2018, 19(2):100. 
33. Alhaffar BA, Alawabdi R, Barakat L, Kouchaji C: Oral health and socio-economic status among children during Syrian crisis: a cross-sectional study. BMC oral health 2019, 19(1):165.

34. Boyce WT, Den Besten PK, Stamperdahl J, Zhan L, Jiang Y, Adler NE, Featherstone JD: Social inequalities in childhood dental caries: the convergent roles of stress, bacteria and disadvantage. Social science \& medicine 2010, 71(9):1644-1652.

35. Saldūnaitè K, Bendoraitienè EA, Slabšinskienè E, Vasiliauskienè I, Andruškevičienè V, Zūbienè J: The role of parental education and socioeconomic status in dental caries prevention among Lithuanian children. Medicina 2014, 50(3):156-161.

36. Mitha S, EINaem MH, Chandran J, Rajah NP, Fam TY, Babar MG, Siddiqui MJ, Jamshed S: Use of oral cleaning devices and their perceived benefits among Malaysians in Kuala Lumpur and Johor Bahru: An exploratory structured approach. Journal of pharmacy \& bioallied sciences 2018, 10(4):216.

37. Goodarzi A, Heidarnia A, Tavafian SS, Eslami M: Evaluation of decayed, missing and filled teeth (DMFT) index in the 12 years old students of Tehran City, Iran. Brazilian Journal of Oral Sciences 2018, 17:18888.

38. Kumar S, Tadakamadla J, Johnson N: Effect of toothbrushing frequency on incidence and increment of dental caries: a systematic review and meta-analysis. Journal of dental research 2016, 95(11):1230-1236.

39. Al-Meedani LA, Al-Dlaigan YH: Prevalence of dental caries and associated social risk factors among preschool children in Riyadh, Saudi Arabia. Pakistan journal of medical sciences 2016, 32(2):452.

\section{Tables}

Table 1. Demographic Characteristics and its Relation to the DMFT Index 


\begin{tabular}{|c|c|c|c|c|c|c|c|c|c|c|c|}
\hline \multirow{2}{*}{\multicolumn{2}{|c|}{ Variable }} & \multicolumn{2}{|c|}{ DT } & \multicolumn{2}{|c|}{$\mathrm{MT}$} & \multicolumn{2}{|c|}{ FT } & \multicolumn{2}{|c|}{ DMFT } & \multicolumn{2}{|c|}{$\begin{array}{c}\text { Dental Caries } \\
* * * \\
\mathbf{n}(\%)\end{array}$} \\
\hline & & Mean (SD) & $\begin{array}{l}\text { Mean } \\
\text { Rank }\end{array}$ & Mean (SD) & $\begin{array}{l}\text { Mean } \\
\text { Rank }\end{array}$ & Mean (SD) & $\begin{array}{l}\text { Mean } \\
\text { Rank }\end{array}$ & Mean (SD & $\begin{array}{l}\text { Mean } \\
\text { Rank }\end{array}$ & Yes & No \\
\hline \multirow[t]{5}{*}{ Age } & 9 & $\begin{array}{c}0.538 \\
(1.057) \\
\end{array}$ & 1897.31 & $\begin{array}{c}0.002 \\
(0.045) \\
\end{array}$ & 2107.34 & $\begin{array}{c}0.061 \\
(0.342) \\
\end{array}$ & 2050.13 & $\begin{array}{c}0.6 \\
(1.11) \\
\end{array}$ & 1860.54 & $\begin{array}{r}422 \\
(25.1) \\
\end{array}$ & $\begin{array}{r}1038 \\
(40.8) \\
\end{array}$ \\
\hline & 10 & $\begin{array}{l}0.843 \\
(1.30) \\
\end{array}$ & 2168.79 & $\begin{array}{c}0.002 \\
(0.053) \\
\end{array}$ & 2109.07 & $\begin{array}{c}0.128 \\
(0.530) \\
\end{array}$ & 2117.47 & $\begin{array}{c}0.97 \\
(1.39) \\
\end{array}$ & 2175.18 & $\begin{array}{c}598 \\
(35.6) \\
\end{array}$ & $\begin{array}{r}794 \\
(31.2) \\
\end{array}$ \\
\hline & 11 & $\begin{array}{r}1.04 \\
(1.52) \\
\end{array}$ & 2287.21 & $\begin{array}{c}0.012 \\
(0.128) \\
\end{array}$ & 2124.54 & $\begin{array}{c}0.167 \\
(0.582) \\
\end{array}$ & 2176.81 & $\begin{array}{c}1.23 \\
(1.633) \\
\end{array}$ & 2319.81 & $\begin{array}{c}659 \\
(39.2) \\
\end{array}$ & $\begin{array}{c}715 \\
(28.1) \\
\end{array}$ \\
\hline & p-value* & \multicolumn{2}{|c|}{0.000} & \multicolumn{2}{|c|}{0.003} & \multicolumn{2}{|c|}{0.000} & \multicolumn{2}{|c|}{0.000} & \multirow{2}{*}{\multicolumn{2}{|c|}{0.000}} \\
\hline & $\mathrm{df}$ & \multicolumn{2}{|c|}{2} & \multicolumn{2}{|c|}{2} & \multicolumn{2}{|c|}{2} & \multicolumn{2}{|c|}{2} & & \\
\hline \multirow[t]{4}{*}{ Gender } & Female & $\begin{array}{c}1.07 \\
(1.51) \\
\end{array}$ & 2318.01 & $\begin{array}{c}0.004 \\
(0.067) \\
\end{array}$ & 2112.78 & $\begin{array}{c}0.145 \\
(0.558)\end{array}$ & 2140.41 & $\begin{array}{c}1.22 \\
(1.59) \\
\end{array}$ & 2331.87 & $\begin{array}{c}1052 \\
(62.7)\end{array}$ & $\begin{array}{c}1106 \\
(43.4)\end{array}$ \\
\hline & Male & $\begin{array}{c}0.525 \\
(1.014)\end{array}$ & 1900.09 & $\begin{array}{c}0.006 \\
(0.098) \\
\end{array}$ & 2114.25 & $\begin{array}{c}0.089 \\
(0.418)\end{array}$ & 2085.42 & $\begin{array}{c}0.62 \\
(1.11) \\
\end{array}$ & 1885.63 & $\begin{array}{c}627 \\
(37.3) \\
\end{array}$ & $\begin{array}{c}1441 \\
(56.6) \\
\end{array}$ \\
\hline & p-value* & \multicolumn{2}{|c|}{0.000} & \multicolumn{2}{|c|}{0.749} & \multicolumn{2}{|c|}{0.001} & \multicolumn{2}{|c|}{0.000} & \multirow{2}{*}{\multicolumn{2}{|c|}{0.000}} \\
\hline & $\mathrm{z}$ & \multicolumn{2}{|c|}{-12.997} & \multicolumn{2}{|c|}{-0.320} & \multicolumn{2}{|c|}{-3.353} & \multicolumn{2}{|c|}{-13.491} & & \\
\hline \multirow[t]{4}{*}{ Habitant } & Urban & $\begin{array}{c}0.755 \\
(1.281) \\
\end{array}$ & 2076.74 & $\begin{array}{c}0.003 \\
(0.067) \\
\end{array}$ & 2107.06 & $\begin{array}{c}0.117 \\
(0.493) \\
\end{array}$ & 2110.30 & $\begin{array}{c}0.88 \\
(1.38) \\
\end{array}$ & 2075.62 & $\begin{array}{r}1186 \\
(70.8) \\
\end{array}$ & $\begin{array}{c}1883 \\
(74) \\
\end{array}$ \\
\hline & Rural & $\begin{array}{c}0.935 \\
(1.410) \\
\end{array}$ & 2198.76 & $\begin{array}{c}0.010 \\
(0.117) \\
\end{array}$ & 2117.85 & $\begin{array}{c}0.119 \\
(0.502) \\
\end{array}$ & 2109.20 & $\begin{array}{c}1.07 \\
(1.49) \\
\end{array}$ & 2201.76 & $\begin{array}{r}490 \\
(29.2) \\
\end{array}$ & $\begin{array}{l}660 \\
(26) \\
\end{array}$ \\
\hline & p-value* & 0.0 & & & & & & & & & \\
\hline & $\mathrm{z}$ & & & & & & & & & & \\
\hline $\begin{array}{l}\text { Father's } \\
\text { education }\end{array}$ & Elementary & $\begin{array}{l}0.784 \\
(1.22) \\
\end{array}$ & 2097.07 & $\begin{array}{c}0.009 \\
(0.108) \\
\end{array}$ & 2086.24 & $\begin{array}{c}0.073 \\
(0.357) \\
\end{array}$ & 2037.94 & $\begin{array}{c}0.87 \\
(1.29) \\
\end{array}$ & 2066.91 & $\begin{array}{c}341 \\
(20.6) \\
\end{array}$ & $\begin{array}{c}503 \\
(201) \\
\end{array}$ \\
\hline level & $\begin{array}{c}\text { Diploma } \\
\text { and Under } \\
\text { diploma }\end{array}$ & $\begin{array}{l}0.875 \\
(1.37)\end{array}$ & 2127.18 & $\begin{array}{c}0.006 \\
(0.091)\end{array}$ & 2081.32 & $\begin{array}{c}0.123 \\
(0.516)\end{array}$ & 2080.74 & $\begin{array}{c}1.01 \\
(1.47)\end{array}$ & 2126.37 & $\begin{array}{c}980 \\
(59.1)\end{array}$ & $\begin{array}{c}1382 \\
(55.3)\end{array}$ \\
\hline & Academic & $\begin{array}{l}0.655 \\
(1.26) \\
\end{array}$ & 1945.42 & 0 & 2069.00 & $\begin{array}{c}0.152 \\
(0.559) \\
\end{array}$ & 2113.30 & $\begin{array}{c}0.80 \\
(1.37) \\
\end{array}$ & 1974.21 & $\begin{array}{c}336 \\
(20.3) \\
\end{array}$ & $\begin{array}{c}615 \\
(24.6) \\
\end{array}$ \\
\hline & $\mathrm{p}$-value ${ }^{* *}$ & 0.0 & & & & & & & & & \\
\hline & $\mathrm{df}$ & & & & & & & & & & \\
\hline $\begin{array}{l}\text { Mother's } \\
\text { education }\end{array}$ & Elementary & $\begin{array}{l}0.771 \\
(1.24) \\
\end{array}$ & 2087.70 & $\begin{array}{c}0.008 \\
(0.102) \\
\end{array}$ & 2099.67 & $\begin{array}{c}0.073 \\
(0.386) \\
\end{array}$ & 2045.13 & $\begin{array}{c}0.85 \\
(1.31) \\
\end{array}$ & 2056.72 & $\begin{array}{c}441 \\
(26.4) \\
\end{array}$ & $\begin{array}{r}689 \\
(49.7) \\
\end{array}$ \\
\hline level & $\begin{array}{c}\text { Diploma } \\
\text { and Under } \\
\text { diploma }\end{array}$ & $\begin{array}{l}0.905 \\
(1.41)\end{array}$ & 2159.13 & $\begin{array}{c}0.004 \\
(0.074)\end{array}$ & 2019.69 & $\begin{array}{c}0.125 \\
(0.516)\end{array}$ & 2099.25 & $\begin{array}{c}1.04 \\
(1.50)\end{array}$ & 2159.37 & $\begin{array}{c}917 \\
(54.9)\end{array}$ & $\begin{array}{c}1251 \\
(49.7)\end{array}$ \\
\hline & Academic & $\begin{array}{c}0.613 \\
(1.168) \\
\end{array}$ & 1940.66 & $\begin{array}{c}0.004 \\
(0.082) \\
\end{array}$ & 2090.08 & $\begin{array}{c}0.161 \\
(0.567) \\
\end{array}$ & 2141.03 & $\begin{array}{c}0.77 \\
(1.29) \\
\end{array}$ & 1979.49 & $\begin{array}{c}312 \\
(18.7) \\
\end{array}$ & $\begin{array}{r}576 \\
(22.9) \\
\end{array}$ \\
\hline & p-value ${ }^{* *}$ & 0.0 & & & & & & & & & \\
\hline & $\mathrm{df}$ & & & & & & & & & & \\
\hline Insurance & Yes & $\begin{array}{l}0.806 \\
(1.31) \\
\end{array}$ & 2114.79 & $\begin{array}{c}0.006 \\
(0.086) \\
\end{array}$ & 2114.12 & $\begin{array}{c}0.118 \\
(0.496) \\
\end{array}$ & 2114.59 & $\begin{array}{c}0.93 \\
(1.41) \\
\end{array}$ & 2115.44 & $\begin{array}{r}1588 \\
(94.6) \\
\end{array}$ & $\begin{array}{r}2404 \\
(94.3) \\
\end{array}$ \\
\hline & No & $\begin{array}{l}0.772 \\
(1.35) \\
\end{array}$ & 2091.73 & 0 & 2103.00 & $\begin{array}{c}0.109 \\
(0.483) \\
\end{array}$ & 2095.22 & $\begin{array}{r}0.88 \\
(1.41) \\
\end{array}$ & 2080.93 & $\begin{array}{c}91 \\
(5.4) \\
\end{array}$ & $\begin{array}{r}146 \\
(5.7) \\
\end{array}$ \\
\hline & p-value* & 0.7 & & & & & & & & & \\
\hline & $\mathrm{z}$ & -03 & & -1 . & & -0 . & & & & & \\
\hline $\begin{array}{c}\text { Father's } \\
\text { Job }\end{array}$ & Unemployed & $\begin{array}{r}1.03 \\
(1.54) \\
\end{array}$ & 2210.30 & $\begin{array}{c}0.019 \\
(0.140) \\
\end{array}$ & 2117.89 & $\begin{array}{c}0.019 \\
(0.140) \\
\end{array}$ & 1983.02 & $\begin{array}{r}1.08 \\
(1.62) \\
\end{array}$ & 2131.14 & $\begin{array}{c}20 \\
(1.2) \\
\end{array}$ & $\begin{array}{c}31 \\
(1.2) \\
\end{array}$ \\
\hline & $\begin{array}{c}\text { Self- } \\
\text { Employee }\end{array}$ & $\begin{array}{l}0.844 \\
(1.34)\end{array}$ & 2117.95 & $\begin{array}{c}0.006 \\
(0.086)\end{array}$ & 2088.59 & $\begin{array}{c}0.111 \\
(0.479)\end{array}$ & 2080.30 & $\begin{array}{c}0.96 \\
(1.43)\end{array}$ & 2109.15 & $\begin{array}{l}1245 \\
(74.9)\end{array}$ & $\begin{array}{l}1815 \\
(72.3)\end{array}$ \\
\hline & Retired & $\begin{array}{l}0.739 \\
(1.30) \\
\end{array}$ & 2021.34 & $\begin{array}{c}0.021 \\
(0.187) \\
\end{array}$ & 2106.45 & $\begin{array}{c}0.154 \\
(0.562) \\
\end{array}$ & 2121.09 & $\begin{array}{c}0.92 \\
(1.40) \\
\end{array}$ & 2070.56 & $\begin{array}{c}55 \\
(3.3) \\
\end{array}$ & $\begin{array}{c}87 \\
(3.5) \\
\end{array}$ \\
\hline & & 0.677 & 1989.73 & 0.001 & 2079.26 & 0.146 & 2112.04 & 0.82 & 2015.77 & 343 & 578 \\
\hline
\end{tabular}




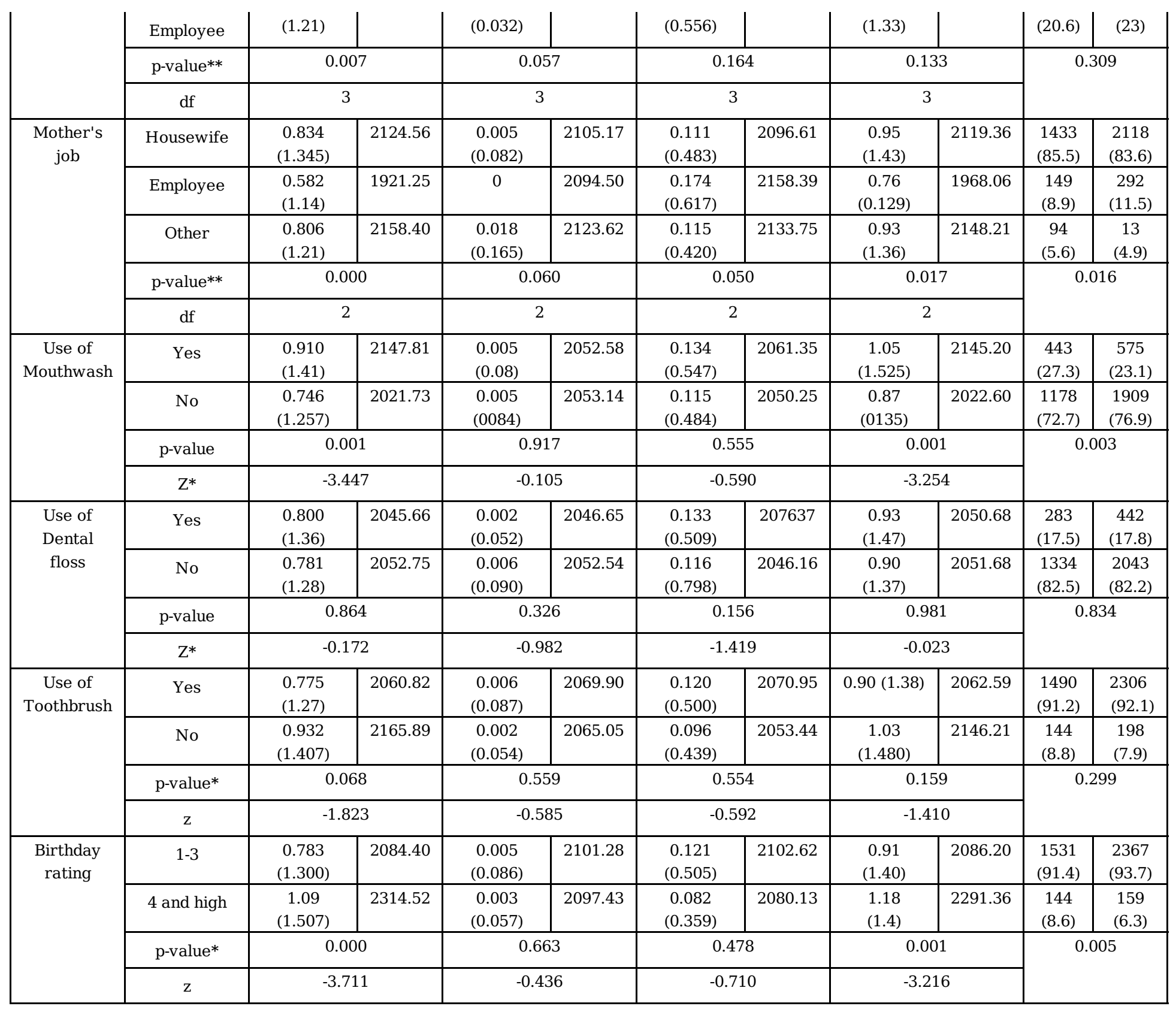

* Mann-Whitney Test; ** Kruskal-Wallis Test; ** Chi-Square Test; DMFT (DT = Decayed teeth, FT = Filled teeth, MT = Missing teeth, DMFT = Decayed, missing and filled teeth.)

Table 2. Demographic Characteristics and its Relation to the dmft Index 


\begin{tabular}{|c|c|c|c|c|c|c|c|c|c|c|c|}
\hline \multirow{2}{*}{\multicolumn{2}{|c|}{ Variable }} & \multicolumn{2}{|c|}{$\mathrm{dt}$} & \multicolumn{2}{|c|}{$\mathrm{mt}$} & \multicolumn{2}{|c|}{$\mathrm{ft}$} & \multicolumn{2}{|c|}{ dmft } & \multicolumn{2}{|c|}{$\begin{array}{c}\text { Dental Caries } \\
* * * \\
\mathbf{n}(\%) \\
\end{array}$} \\
\hline & & Mean (SD) & $\begin{array}{l}\text { Mean } \\
\text { Rank }\end{array}$ & Mean (SD) & $\begin{array}{l}\text { Mean } \\
\text { Rank }\end{array}$ & Mean (SD) & $\begin{array}{l}\text { Mean } \\
\text { Rank }\end{array}$ & Mean (SD) & $\begin{array}{l}\text { Mean } \\
\text { Rank }\end{array}$ & Yes & No \\
\hline \multirow[t]{5}{*}{ Age } & 9 & $\begin{array}{c}2.56 \\
(2.44)\end{array}$ & 2454.00 & $\begin{array}{c}0.191 \\
(0.657)\end{array}$ & 2168.14 & $\begin{array}{l}0.380 \\
(1.04)\end{array}$ & 2182.47 & $\begin{array}{c}3.14 \\
(2.56)\end{array}$ & 2510.69 & $\begin{array}{c}1156 \\
(40.4)\end{array}$ & $\begin{array}{c}304 \\
(22.3)\end{array}$ \\
\hline & 10 & $\begin{array}{c}2 \\
(2.16) \\
\end{array}$ & 2183.54 & $\begin{array}{c}0.145 \\
(0551) \\
\end{array}$ & 2121.15 & $\begin{array}{c}0.317 \\
(0.946) \\
\end{array}$ & 2143.89 & $\begin{array}{r}2.46 \\
(2.34) \\
\end{array}$ & 2194.45 & $\begin{array}{r}995 \\
(34.8) \\
\end{array}$ & $\begin{array}{c}397 \\
(29.1) \\
\end{array}$ \\
\hline & 11 & $1.133(1.71)$ & 1680.74 & $\begin{array}{r}0.080 \\
(0.394) \\
\end{array}$ & 2047.69 & $\begin{array}{r}0.158 \\
(0.597) \\
\end{array}$ & 2009.43 & $\begin{array}{r}1.37 \\
(1.84) \\
\end{array}$ & 1609.44 & $\begin{array}{r}711 \\
(24.8) \\
\end{array}$ & $\begin{array}{c}663 \\
(48.6) \\
\end{array}$ \\
\hline & p-value* & \multicolumn{2}{|c|}{0.000} & \multicolumn{2}{|c|}{0.000} & \multicolumn{2}{|c|}{0.000} & \multicolumn{2}{|c|}{0.000} & \multirow{2}{*}{\multicolumn{2}{|c|}{0.000}} \\
\hline & $\mathrm{z}$ & \multicolumn{2}{|c|}{2} & \multicolumn{2}{|c|}{2} & \multicolumn{2}{|c|}{2} & \multicolumn{2}{|c|}{2} & & \\
\hline \multirow[t]{4}{*}{ Gender } & Female & $\begin{array}{r}1.80 \\
(2.04) \\
\end{array}$ & 2069.93 & $\begin{array}{c}0.135 \\
(0.546) \\
\end{array}$ & 2105.63 & $\begin{array}{r}0.302 \\
(0.922) \\
\end{array}$ & 2126.05 & $\begin{array}{r}2.22 \\
(2.21) \\
\end{array}$ & 2080.36 & $\begin{array}{c}146 \\
(51.1) \\
\end{array}$ & $\begin{array}{r}696 \\
(51) \\
\end{array}$ \\
\hline & Male & $\begin{array}{c}2.04 \\
(2.37) \\
\end{array}$ & 2158.97 & $\begin{array}{c}0.145 \\
(0.533)\end{array}$ & 2121.71 & $\begin{array}{c}0.272 \\
(0.858)\end{array}$ & 2100.40 & $\begin{array}{c}2.47 \\
(2.55)\end{array}$ & 2148.08 & $\begin{array}{c}1400 \\
(48.9)\end{array}$ & $\begin{array}{l}668 \\
(49)\end{array}$ \\
\hline & p-value* & \multicolumn{2}{|c|}{0.014} & \multicolumn{2}{|c|}{0.366} & \multicolumn{2}{|c|}{0.253} & \multicolumn{2}{|c|}{0.065} & \multirow{2}{*}{\multicolumn{2}{|c|}{0.974}} \\
\hline & $\mathrm{z}$ & \multicolumn{2}{|c|}{-2.456} & \multicolumn{2}{|c|}{-0.904} & \multicolumn{2}{|c|}{-1.144} & \multicolumn{2}{|c|}{-1.843} & & \\
\hline \multirow[t]{4}{*}{ Habitant } & Urban & $\begin{array}{c}1.77 \\
(2.17) \\
\end{array}$ & 2032.32 & $\begin{array}{c}0.115 \\
(0.490)\end{array}$ & 2084.97 & $\begin{array}{c}0.325 \\
(0.953) \\
\end{array}$ & 21.40 .76 & $\begin{array}{c}2.22 \\
(2.36) \\
\end{array}$ & 2043.36 & $\begin{array}{l}2015 \\
(705)\end{array}$ & $\begin{array}{l}1054 \\
(77.4)\end{array}$ \\
\hline & Rural & $\begin{array}{r}2.27 \\
(2.29) \\
\end{array}$ & 2317.30 & $\begin{array}{r}0.208 \\
(0.679) \\
\end{array}$ & 2176.80 & $\begin{array}{c}0.188 \\
(0.696) \\
\end{array}$ & 2027.90 & $\begin{array}{r}2.67 \\
(2.43) \\
\end{array}$ & 2287.83 & $\begin{array}{r}843 \\
(29.5) \\
\end{array}$ & $\begin{array}{c}307 \\
(22.6) \\
\end{array}$ \\
\hline & p-value** & 0.0 & & 0.0 & & 0.0 & & 0.00 & & & \\
\hline & $\mathrm{df}$ & 1 & & 1 & & 1 & & 1 & & & \\
\hline $\begin{array}{l}\text { Father's } \\
\text { education }\end{array}$ & Elementary & $\begin{array}{c}2.03 \\
(2.19) \\
\end{array}$ & 2173.09 & $\begin{array}{c}0.148 \\
(0.540) \\
\end{array}$ & 2090.71 & $\begin{array}{c}0.069 \\
(0.365) \\
\end{array}$ & 1886.24 & $\begin{array}{r}2.26 \\
(2.26) \\
\end{array}$ & 2061.99 & $\begin{array}{c}588 \\
(20.9) \\
\end{array}$ & $\begin{array}{c}256 \\
(19.1) \\
\end{array}$ \\
\hline level & $\begin{array}{c}\text { Diploma } \\
\text { and Under } \\
\text { diploma }\end{array}$ & $\begin{array}{c}1.97 \\
(2.25)\end{array}$ & 2108.57 & $\begin{array}{c}0.146 \\
(0.559)\end{array}$ & 2086.41 & $\begin{array}{c}0.218 \\
(0.772)\end{array}$ & 2016.84 & $\begin{array}{c}2.34 \\
(2.41)\end{array}$ & 2073.02 & $\begin{array}{c}1584 \\
(56.2)\end{array}$ & $\begin{array}{c}779 \\
(58.2)\end{array}$ \\
\hline & Academic & $\begin{array}{c}1.64 \\
(2.10) \\
\end{array}$ & 1924.22 & $\begin{array}{c}0.118 \\
(0.524) \\
\end{array}$ & 2052.39 & $\begin{array}{l}0.664 \\
(1.31) \\
\end{array}$ & 2406.70 & $\begin{array}{c}2.42 \\
(2.44) \\
\end{array}$ & 2111.14 & $\begin{array}{l}647 \\
(23) \\
\end{array}$ & $\begin{array}{c}304 \\
(22.7) \\
\end{array}$ \\
\hline & p-value** & 0.0 & & 0.0 & & 0.0 & & 0.00 & & & \\
\hline & $\mathrm{df}$ & 2 & & 2 & & 2 & & 2 & & & \\
\hline $\begin{array}{l}\text { Mother's } \\
\text { education }\end{array}$ & Elementary & $\begin{array}{r}1.91 \\
(2.14) \\
\end{array}$ & 2120.53 & $\begin{array}{c}0.167 \\
(0.609) \\
\end{array}$ & 2118.05 & $\begin{array}{c}0.086 \\
(0.470) \\
\end{array}$ & 1907.44 & $\begin{array}{r}2.17 \\
(2.24) \\
\end{array}$ & 2026.24 & $\begin{array}{r}758 \\
(26.7) \\
\end{array}$ & $\begin{array}{c}372 \\
(27.6) \\
\end{array}$ \\
\hline level & $\begin{array}{c}\text { Diploma } \\
\text { and Under } \\
\text { diploma }\end{array}$ & $\begin{array}{c}2 \\
(2.26)\end{array}$ & 2131.81 & $\begin{array}{c}0.135 \\
(0.513)\end{array}$ & 2092.79 & $\begin{array}{c}0.256 \\
(0.829)\end{array}$ & 2064.71 & $\begin{array}{c}2.39 \\
(2.41)\end{array}$ & 2110.09 & $\begin{array}{c}1469 \\
(51.7)\end{array}$ & $\begin{array}{c}699 \\
(51.9)\end{array}$ \\
\hline & Academic & $\begin{array}{r}1.72 \\
(2.19) \\
\end{array}$ & 1965.58 & $\begin{array}{c}0.119 \\
(0.546) \\
\end{array}$ & 2064.00 & $\begin{array}{l}0.629 \\
(1.28) \\
\end{array}$ & 2400.56 & $\begin{array}{c}2.46 \\
(2.50) \\
\end{array}$ & 2138.59 & $\begin{array}{r}612 \\
(21.6) \\
\end{array}$ & $\begin{array}{c}276 \\
(20.5) \\
\end{array}$ \\
\hline & p-value** & 0.0 & & 0.1 & & 0.0 & & 0.06 & & & \\
\hline & $\mathrm{df}$ & 2 & & 2 & & 2 & & 2 & & & \\
\hline Insurance & Yes & $\begin{array}{c}1.86 \\
(2.18)\end{array}$ & 2087.71 & $\begin{array}{c}0.142 \\
(0.551)\end{array}$ & 2115.74 & $\begin{array}{c}0.284 \\
(0.885)\end{array}$ & 2111.32 & $\begin{array}{c}2.29 \\
(2.35)\end{array}$ & 2089.25 & $\begin{array}{c}2679 \\
(93.6)\end{array}$ & $\begin{array}{l}1310 \\
(96)\end{array}$ \\
\hline & No & $\begin{array}{c}2.79 \\
(2.61)\end{array}$ & 2547.59 & $\begin{array}{c}0.113 \\
(0.512)\end{array}$ & 2075.87 & $\begin{array}{c}0.346 \\
(0.990)\end{array}$ & 215021 & $\begin{array}{c}3.25 \\
(2.77)\end{array}$ & 2521.68 & $\begin{array}{l}183 \\
(6.4)\end{array}$ & $\begin{array}{l}54 \\
(4)\end{array}$ \\
\hline & p-value* & 0.0 & & 0.3 & & 0.4 & & 0.00 & & & \\
\hline & $\mathrm{z}$ & -5.8 & & -1.0 & & -0.7 & & -5.4 & & & \\
\hline $\begin{array}{c}\text { Father's } \\
\text { Job }\end{array}$ & Unemployed & $\begin{array}{c}2.31 \\
(2.587) \\
\end{array}$ & 2231.70 & $\begin{array}{c}0.137 \\
(0.448) \\
\end{array}$ & 2121.31 & $\begin{array}{c}0.098 \\
(0.458) \\
\end{array}$ & 1920.28 & $\begin{array}{r}2.55 \\
(2.61) \\
\end{array}$ & 2143.18 & $\begin{array}{c}33 \\
(1.2) \\
\end{array}$ & $\begin{array}{c}18 \\
(1.3) \\
\end{array}$ \\
\hline & $\begin{array}{c}\text { Self- } \\
\text { Employee }\end{array}$ & $\begin{array}{c}2 \\
(2.23)\end{array}$ & 2138.07 & $\begin{array}{c}0.137 \\
(0.523)\end{array}$ & 2092.56 & $\begin{array}{c}0.192 \\
(0.720)\end{array}$ & 2002.37 & $\begin{array}{c}2.33 \\
(2.36)\end{array}$ & 2084.37 & $\begin{array}{c}2089 \\
(73.9)\end{array}$ & $\begin{array}{c}971 \\
(72.1)\end{array}$ \\
\hline & Retired & $\begin{array}{c}1.42 \\
(2.01) \\
\end{array}$ & 1792.22 & $\begin{array}{c}0.056 \\
(0.260) \\
\end{array}$ & 2018.90 & $\begin{array}{l}0.507 \\
(1.20) \\
\end{array}$ & 2237.58 & $\begin{array}{c}1.98 \\
(2.32) \\
\end{array}$ & 1875.24 & $\begin{array}{c}81 \\
(2.9) \\
\end{array}$ & $\begin{array}{c}61 \\
(4.5) \\
\end{array}$ \\
\hline & & 1.70 & 1957.02 & 0.156 & 2079.40 & 0.586 & 2356.48 & 2.44 & 2127.54 & 625 & 296 \\
\hline
\end{tabular}




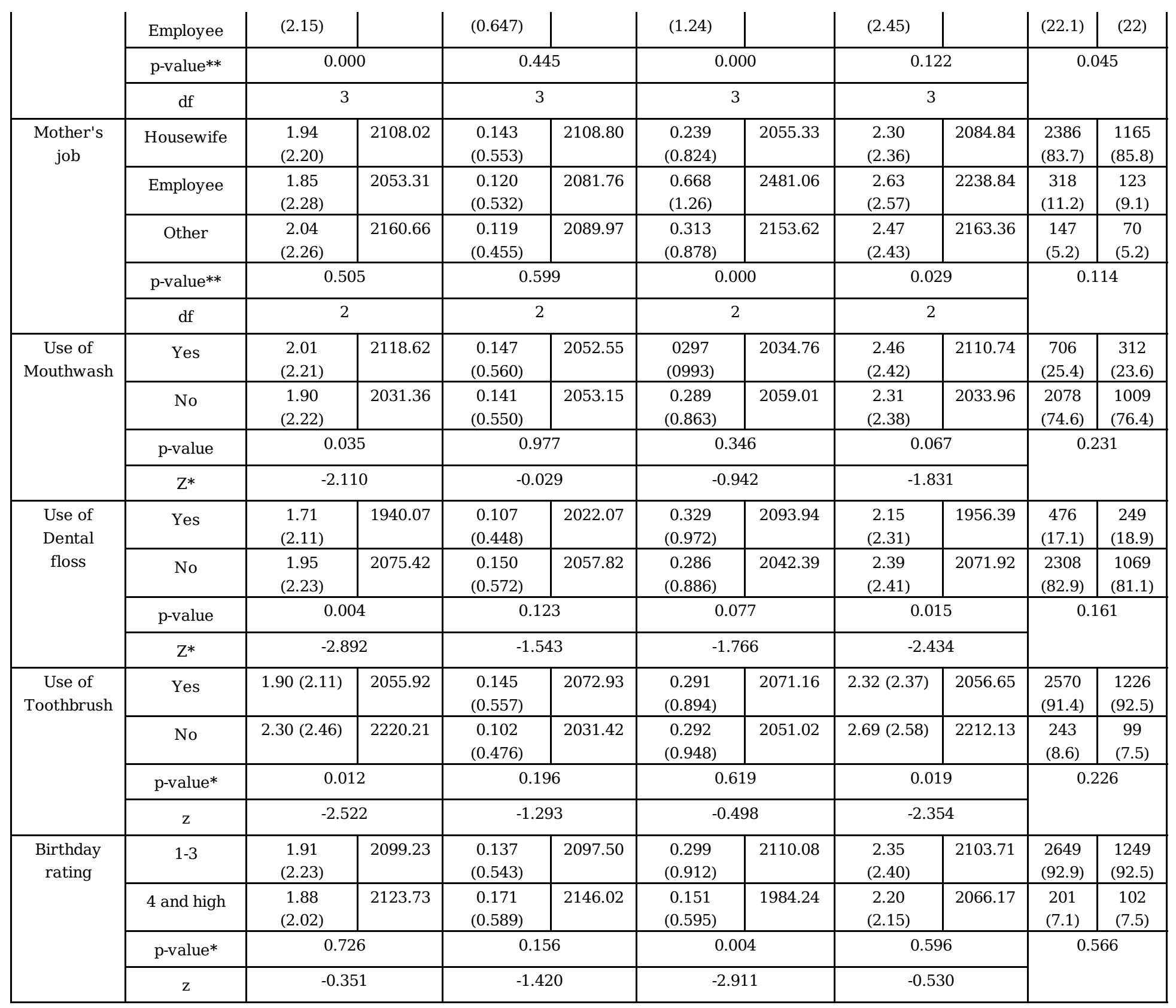

* Mann-Whitney Test; ** Kruskal-Wallis Test; $* *$ Chi-Square Tests; dmft(dt = Decayed teeth, $\mathrm{ft}=$ Filled teeth, $\mathrm{mt}=\mathrm{Missing}$ teeth, $\mathrm{dmft}=\mathrm{Decayed}$, missing and filled teeth.)

Table 3. Relationship between children's DMFT index of 9-11 years old and variables included in the study using logistic regression 


\begin{tabular}{|c|c|c|c|c|c|c|c|c|c|}
\hline \multicolumn{2}{|c|}{ Variables } & \multicolumn{4}{|c|}{ Univariate Regression } & \multicolumn{4}{|c|}{ Multiple Regression } \\
\hline & & $\mathrm{r}$ & OR & $95 \%$ C.I & P-Value & $\mathrm{r}$ & OR & $95 \%$ C.I & P-Value \\
\hline \multirow[t]{2}{*}{ Gender } & Male & Reference & & & & Reference & & & \\
\hline & Female & 0.78 & 2.18 & $1.92-2.48$ & $<0.001$ & 0.73 & 2.08 & $1.83-2.37$ & $<0.001$ \\
\hline \multirow[t]{2}{*}{ Birthday rating } & $1-3$ & Reference & & & & Reference & & & \\
\hline & 4 or high & 0.33 & 1.40 & $1.10-1.7$ & 0.005 & 0.32 & 1.38 & $1.07-1.78$ & 0.01 \\
\hline \multirow[t]{2}{*}{ Insurance } & No & Reference & & & & & & & \\
\hline & Yes & 0.05 & 1.06 & 0.81-1.39 & 0.66 & - & - & - & - \\
\hline \multirow[t]{3}{*}{ Education level Father } & Elementary & Reference & & & & Reference & & & \\
\hline & Diploma and Under diploma & 0.04 & 1.04 & $0.89-1.22$ & 0.58 & -0.07 & 0.93 & $0.77-1.12$ & 0.46 \\
\hline & Academic & -0.21 & 0.80 & 0.66-0.97 & 0.02 & -0.25 & 0.77 & 0.61-0.99 & 0.04 \\
\hline \multirow[t]{3}{*}{ Education level Mother } & Elementary & Reference & & & & Reference & & & \\
\hline & Diploma and Under diploma & 0.13 & 1.14 & $0.98-1.32$ & 0.07 & 0.22 & 1.25 & $1.04-1.49$ & 0.01 \\
\hline & Academic & -0.16 & 0.84 & $0.70-1.01$ & 0.07 & 0.09 & 1.09 & 0.84-1.42 & 0.48 \\
\hline \multirow[t]{4}{*}{ Father's Job } & Unemployed & Reference & & & & & & & \\
\hline & Self- Employee & 0.06 & 1.06 & $0.60-1.87$ & 0.83 & - & - & - & - \\
\hline & Retired & -0.02 & 0.98 & $0.50-1.88$ & 0.95 & - & - & - & - \\
\hline & Employee & -0.08 & 0.92 & $0.51-1.63$ & 0.77 & - & - & - & - \\
\hline \multirow[t]{3}{*}{ Mother's job } & Housewife & Reference & & & & Reference & & & \\
\hline & Employee & -0.28 & 0.75 & $0.61-0.92$ & 0.008 & -0.10 & 0.90 & $0.69-1.18$ & 0.45 \\
\hline & Others & 0.12 & 1.13 & $0.85-1.49$ & 0.38 & 0.15 & 1.16 & $0.87-1.56$ & 0.29 \\
\hline \multirow[t]{2}{*}{ Habitant } & Rural & Reference & & & & Reference & & & \\
\hline & Urban & 0.16 & 1.18 & $1.02-1.35$ & 0.02 & 0.17 & 1.18 & $1.02-1.37$ & 0.02 \\
\hline \multirow[t]{2}{*}{ Use of Toothbrush } & Yes & Reference & & & & & & & \\
\hline & No & 0.12 & 1.12 & $0.89-1.40$ & 0.30 & - & & - & - \\
\hline \multirow[t]{2}{*}{ Use of Mouthwash } & Yes & Reference & & & & Reference & & & \\
\hline & No & -0.22 & 0.80 & 0.69-0.92 & 0.002 & -0.16 & 0.84 & 0.73-0.98 & 0.02 \\
\hline \multirow[t]{2}{*}{ Use of Dental floss } & Yes & Reference & & & & & & & \\
\hline & No & 0.02 & 1.02 & $0.86-1.20$ & 0.81 & - & & - & - \\
\hline
\end{tabular}

Table 4. Relationship between children's dmft index of 9-11 years old and variables included in the study using logistic regression 


\begin{tabular}{|c|c|c|c|c|c|c|c|c|c|}
\hline \multicolumn{2}{|c|}{ Variables } & \multicolumn{4}{|c|}{ Univariate Regression } & \multicolumn{4}{|c|}{ Multiple Regression } \\
\hline & & $\mathrm{r}$ & OR & $95 \%$ C.I & P-Value & $\mathrm{r}$ & OR & $95 \%$ C.I & P-Value \\
\hline \multirow[t]{2}{*}{ Gender } & Male & Reference & & & & & & & \\
\hline & Female & 0.002 & 1.002 & $0.88-1.14$ & 0.97 & - & - & - & - \\
\hline \multirow[t]{2}{*}{ Birthday rating } & $1-3$ & Reference & & & & & & & \\
\hline & 4 or high & -0.07 & 0.92 & $0.72-1.19$ & 0.56 & - & - & - & - \\
\hline \multirow[t]{2}{*}{ Insurance } & No & Reference & & & & Reference & & & \\
\hline & Yes & -0.50 & 0.60 & $0.44-0.82$ & 0.001 & -0.54 & 0.57 & $0.41-0.78$ & 0.001 \\
\hline \multirow[t]{3}{*}{ Education level Father } & Elementary & Reference & & & & Reference & & & \\
\hline & Diploma and Under diploma & -0.12 & 0.88 & $0.74-1.04$ & 0.16 & -0.07 & 0.92 & $0.77-1.10$ & 0.41 \\
\hline & Academic & -0.07 & 0.92 & $0.75-1.13$ & 0.45 & -0.03 & 0.96 & $0.77-1.20$ & 0.76 \\
\hline \multirow[t]{3}{*}{ Education level Mother } & Elementary & Reference & & & & & & & \\
\hline & Diploma and Under diploma & 0.03 & 1.03 & $0.88-1.20$ & 0.69 & - & - & - & - \\
\hline & Academic & 0.38 & 1.08 & 0.90 .131 & 0.38 & - & - & - & - \\
\hline \multirow[t]{4}{*}{ Father's Job } & Unemployed & Reference & & & & & & & \\
\hline & Self- Employee & 0.16 & 1.17 & $0.65-2.09$ & 0.58 & - & - & - & - \\
\hline & Retired & -0.32 & 0.72 & $0.37-1.40$ & 0.34 & - & - & - & - \\
\hline & Employee & 0.14 & 1.15 & $0.63-2.07$ & 0.63 & - & - & - & - \\
\hline \multirow[t]{3}{*}{ Mother's job } & Housewife & Reference & & & & Reference & & & \\
\hline & Employee & 0.263 & 1.26 & $1.01-1.57$ & 0.03 & 0.29 & 1.34 & $1.05-1.70$ & 0.01 \\
\hline & Others & 0.02 & 1.02 & $0.76-1.37$ & 0.86 & 0.06 & 1.06 & $0.78-1.43$ & 0.69 \\
\hline \multirow[t]{2}{*}{ Habitant } & Rural & Reference & & & & Reference & & & \\
\hline & Urban & 0.36 & 1.43 & $1.23-1.66$ & $<0.001$ & 0.41 & 1.50 & $1.28-1.76$ & $<0.001$ \\
\hline \multirow[t]{2}{*}{ Use of Toothbrush } & Yes & Reference & & & & & & & \\
\hline & No & 0.16 & 1.17 & $0.91-1.49$ & 0.204 & - & & - & - \\
\hline \multirow[t]{2}{*}{ Use of Mouthwash } & Yes & Reference & & & & & & & \\
\hline & No & -0.09 & 0.91 & $0.78-1.06$ & 0.22 & - & & - & - \\
\hline \multirow[t]{2}{*}{ Use of Dental floss } & Yes & Reference & & & & Reference & & & \\
\hline & No & 0.12 & 1.12 & $0.95-1.33$ & 0.16 & 0.12 & 1.12 & $0.95-1.34$ & 0.16 \\
\hline
\end{tabular}

